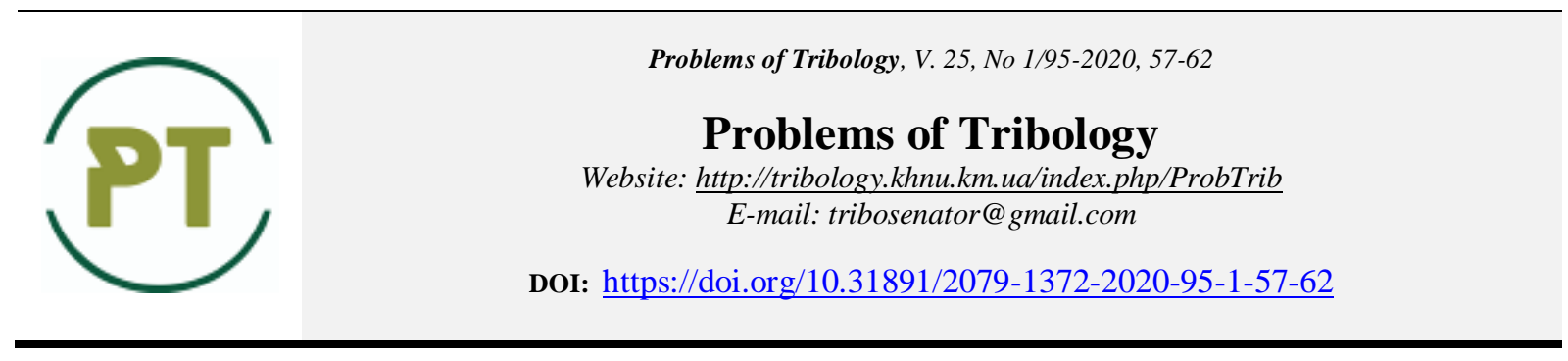

\title{
Effect of plant remains on abrasive wear rate of the tilling machine movable operating parts
}

\author{
K.V. Borak \\ Zhytomyr Agrarian and Technical College, Ukraine \\ E-mail: koss1983@meta.ua
}

\begin{abstract}
Abrasive wear is one of the most common types of wear accounting for up to 50\% of all failures of machine parts. The study of laws governing the process of abrasive wear process is undoubtedly a critical task. The paper is dedicated to the effect that the chemical factor, in particular the presence of plant remains in the abrasive mass, has on the tilling machine movable operating parts abrasive wear rate. Laboratory researches were performed with the Impeller technique, while the field tests - with a multipurpose disk tiller UDA-4.5 in the conditions of the Ovruch district of Zhytomyr region (sandy loam soil). As follows from the study, the ooze of the sap (syrup) leads to an increase of the abrasive wear rate by $13.5 \ldots 21.5 \%$ in the laboratory conditions and by $8 \%$ in the field conditions. Results of the field tests confirm those of the laboratory studies, although the latter have demonstrated an increase in the wear rate, which is by $13.5 \%$ greater than got upon the field tests. Such a deviation is conditioned by a higher concentration of the corn crop remains in the abrasive mass during laboratory testing. Abrasive wear of the tilling machine movable operating parts may not be identified as a simple mechanical process, as the working surface wear rate may be significantly increased by the chemical factor when subject to wear in the real soil.
\end{abstract}

Key words: movable operating parts, tilling machines, abrasive wear, soil, plant remains

\section{Introduction}

In terms of economics, the cost of abrasion wear alone has been estimated as ranging from 1 to $4 \%$ of the gross national product of a sound industrialized nation [1]. A significant number of works have been devoted to the abrasive wear mechanism study. The nature of abrasive wear and the multiple factor impact on the abrasive wear mechanism have been investigated in laboratory and field conditions, but plenty of things within the process remains unclear. Works of the abrasive wear regularity forebears $[2,3,4]$ are based upon the consideration that the abrasive wear is the most straightforward kind of destruction of the surface layers during friction. The abrasive wear is substantially described in terms of the physical theory of strength and ductility of metals, as well as the theory of metal cutting, in consideration at the same time of the geometry and size of the abrasive particles [1]. No chemical processes that may have occurred on the friction surface during abrasive wear are not taken into account with the mentioned approach.

\section{Literature review}

A significant number of works have been devoted to the study of factors affecting the abrasive wear rate. As noted in the work [5], the U.S. media have been covering the abrasive wear (in particular when it comes to the conventional ideas thereof) far less than all other ones. The same trend is also characteristic of the countries of Western Europe. All Western researchers of the abrasive wear refer in their works upon the researches of the Soviet scientists, in particular the early works of M. Khrushchev [2,3]. It should be noted that the effect of material hardness on the wear rate has been qualitatively studied in the works of U.S. scientists [6,7]. The result is that the researchers have found that the hardness cannot serve as a universal indicator of the material wear resistance; however, the material structure shall be studied $[6,7]$. 
The effects that the abrasive particle hardness $[8,9,10]$, abrasive particle size $[11,12,13,14]$ and abrasive particle shape $[9,10,15,16,17]$ may have on the wear rate have been investigated in a number of works of both domestic and foreign researchers. All such studies assumed the use of an 'ultimate' abrasive material, which properties differ significantly from those conforming to the actual operating conditions of the tilling machine movable parts. Further to the mentioned studies, it should be noted that the only comparative characteristics may be determined, but not the real processes taking place with abrasive wear in the friction zone may be described thereby.

As it follows from the analysis of the works of both domestic and foreign authors, factors, whereby the parts wear rate is affected with abrasive wear have been not yet studied enough. The vast majority of researchers do not consider the chemical factor impact on the interaction of abrasive mass with the surface of machine parts exposed to abrasive wear. This is an unacceptable error when it comes to the tilling machine movable operating parts as soil components (plant remains, living organisms, acids, organic compounds, etc.) may provoke chemical processes intensifying or slowing down the abrasive wear of the tilling machine movable operating part surface.

\section{Purpose}

The purpose hereof is to study the effect of plant remains on the tilling machine movable operating parts abrasive wear rate.

\section{Methods}

Laboratory researches of the effects that plant remains may have on the tilling machine movable operating parts abrasive wear rate were performed with the enhanced Impeller technique (see Fig.1).

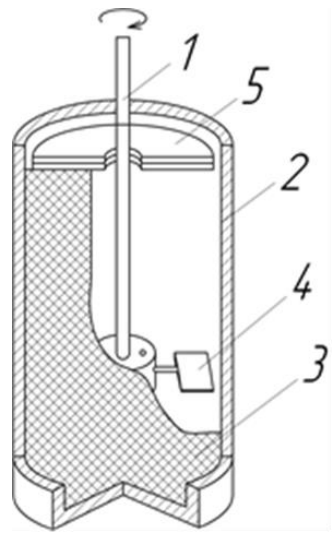

Fig. 1. Test performed with enhanced Impeller technique:

1- The sample holding shaft; 2- Cylinder; 3- Abrasive mass 4- Samples;

5- Multisectional disk used to provide the required density of the abrasive mass

Installation was driven by a spindle of the vertical boring machine 2E78P (see Fig. 2)

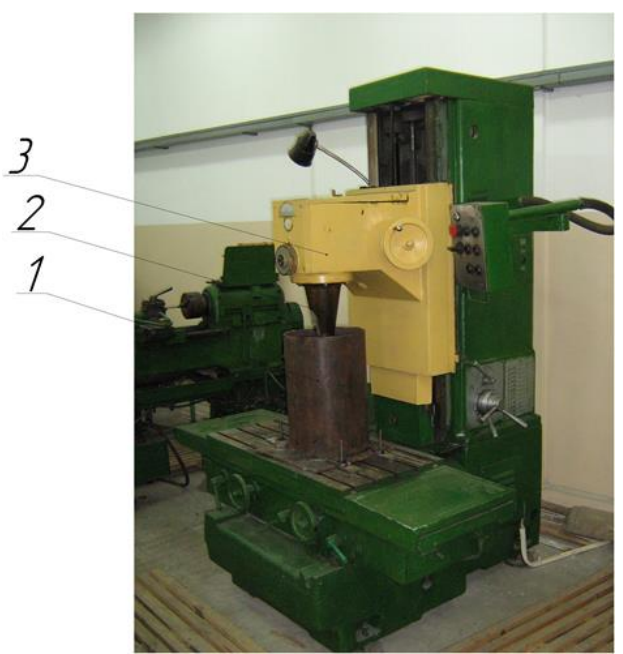

Fig. 2. Wear strength test installation. General view:

1-Cylinder with abrasive mass; 2- The sample holding shaft; 3 - Vertical boring machine 2E78P 
The weight wear of the samples was determined with laboratory scales CP 34001 S (manufacturer Sartorius). The friction path was considered to be $100 \mathrm{~km}$. Frequency of weight loss control of the sample on the path: 5 (five times) or after every $20 \mathrm{~km}$. Traveling speed of $125.28 \mathrm{~m} / \mathrm{min}$ and mixture pressure of $122.6 \mathrm{kPa}$ (applied to a sample) were accepted as a constant factor. Quartz sand with a particle size of $50 \ldots 100 \mu \mathrm{m}$ was used as a working medium. Abrasive particle shape factor $\mathrm{K}_{\text {shape }}$ of 114.18 was adopted.

Parameters of steel used for the test: grade $65(65 \Gamma)$, bulk-quenched at $810 \ldots 830^{\circ} \mathrm{C}$ and mediumtemperature $\left(460 \ldots 480^{\circ} \mathrm{C}\right)$ tempered with highly accurate exposure time.

\section{Results}

Results obtained upon the studies are shown in Table 1.

As we can see in Table 1, a decrease in the weight wear rate by $4 \ldots 5 \%$ is observed for most dry plant remains, which is explained by a decreased abrasive ability of the working medium due to the availability of plant remains. On the contrary, a minor increase in wear rate by $5 \ldots 9 \%$ was observed in the case of corn, soy, and sunflower crops.

The wear rate increase by $13.5 \ldots 16 \%$ is observed in the moist material, which possible reason may be explained by releasing of the amino acids and amines from the plant remains, thus resulting in the intensification of chemical processes on the friction surface. This statement is also confirmed by the results of tests with abrasive mass containing harvestable plants (in the earing phase for wheat and in the combined wax- and milk-ripe stage for corn). In such a way, the wear rate in the case of wheat was increased by $15.4 \ldots 18.6 \%$, and by $21.5 \%$ for corn. The sap (syrup) oozed by plants in wear has intensified the process of abrasive wear due to the amino acids and amines released.

Table 1.

Sample 65G Steel Weight Wear Rate in Abrasive Mass

\begin{tabular}{|c|c|c|c|}
\hline $\mathrm{S} / \mathrm{n}$ & Abrasive Mass & $\begin{array}{l}\text { Plant remains content } \\
(\% \mathrm{w} / \mathrm{w})\end{array}$ & $\begin{array}{c}\text { Weight Wear Rate, } \\
I_{t} g / k m\end{array}$ \\
\hline 1 & No plant remains & 0 & 0.022 \\
\hline \multicolumn{4}{|c|}{ Plant remains (dry) after agricultural crop harvesting. } \\
\hline \multirow{2}{*}{2} & \multirow{2}{*}{ Soya } & 3 & 0.022 \\
\hline & & 6 & 0.023 \\
\hline \multirow{2}{*}{3} & \multirow{2}{*}{ Soybeans (flaked) } & 3 & 0.021 \\
\hline & & 6 & 0.021 \\
\hline \multirow{2}{*}{4} & \multirow{2}{*}{ Wheat } & 3 & 0.022 \\
\hline & & 6 & 0.021 \\
\hline \multirow{2}{*}{5} & \multirow{2}{*}{ Barley } & 3 & 0.021 \\
\hline & & 6 & 0.022 \\
\hline \multirow{2}{*}{6} & \multirow{2}{*}{ Alfalfa } & 3 & 0.022 \\
\hline & & 6 & 0.021 \\
\hline \multirow{2}{*}{7} & \multirow{2}{*}{ Rape } & 3 & 0.021 \\
\hline & & 6 & 0.021 \\
\hline \multirow{2}{*}{8} & \multirow{2}{*}{ Corn } & 3 & 0.023 \\
\hline & & 6 & 0.022 \\
\hline \multirow{2}{*}{9} & \multirow{2}{*}{ Sunflower } & 3 & 0.022 \\
\hline & & 6 & 0.023 \\
\hline \multirow{2}{*}{10} & \multirow{2}{*}{ Hay (meadow grasses) } & 3 & 0.022 \\
\hline & & 6 & 0.021 \\
\hline \multicolumn{4}{|c|}{ Plant remains (moist) after agricultural crop harvesting. } \\
\hline \multirow{2}{*}{11} & \multirow{2}{*}{$\begin{array}{c}\text { Soya (38\% moisture con- } \\
\text { tent) }\end{array}$} & 3 & 0.024 \\
\hline & & 6 & 0.024 \\
\hline \multirow{2}{*}{12} & \multirow{2}{*}{$\begin{array}{c}\text { Barley (34\% moisture con- } \\
\text { tent) }\end{array}$} & 3 & 0.024 \\
\hline & & 6 & 0.025 \\
\hline \multicolumn{4}{|c|}{ Plants in different growth stages } \\
\hline \multirow{2}{*}{13} & \multirow{2}{*}{ Wheat (in earing phase) } & 3 & 0.026 \\
\hline & & 6 & 0.027 \\
\hline \multirow{2}{*}{14} & \multirow{2}{*}{$\begin{array}{l}\text { Corn (in the combined wax- } \\
\text { and milk-ripe stage) }\end{array}$} & 3 & 0.028 \\
\hline & & 6 & 0.028 \\
\hline
\end{tabular}


In order to confirm the laboratory studies, operational investigations were conducted on two adjacent 56 ha fields. Plots were placed on sandy soils in Ovruch district, Zhytomyr region. The first plot was immediately after harvesting the corn on the silo, the second plot was pure fallow (the field was not cultivated for a year, herbicides were introduced to prevent the presence of plant residues on the surface of the field). The research results are presented in Fig. 3.

The field tests were performed in two adjacent parcels with an area of 56 hectares each to confirm the laboratory findings. The parcels were located within the areas with sandy loam soil in the Ovruch district of the Zhytomyr Region. The first one was immediately after corn silage harvesting, while the other was known to be held as a naked fallow field (the field was not cultivated for a year, herbicides were introduced to prevent the presence of plant remains on the surface of the field). Test results are given in Figure 3.

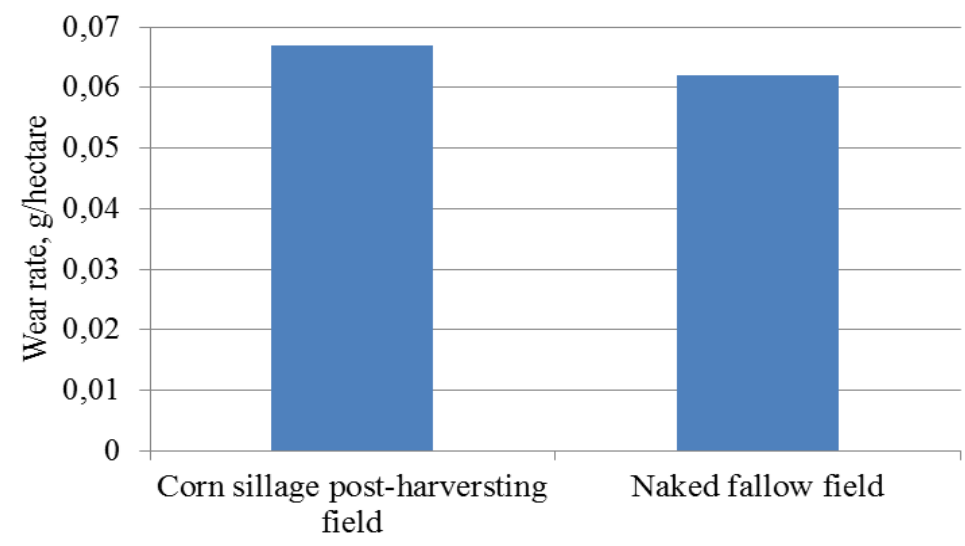

Fig. 3. Multipurpose disk tiller UDA 4.5 movable operating parts wear rate

Eventually, it has been found that the rate of disk-type movable parts (Multipurpose disk tiller UDA 4.5) wear on the corn post-harvesting field is by $8 \%$ higher than the rate of disk-type movable parts wear on the field free of plant remains.

Laboratory findings are confirmed by those of the field tests, although the laboratory results showed an increase of $21.5 \%$ against $8 \%$ demonstrated by the field tests. Such a deviation is conditioned by a higher concentration of the corn crop remains in the abrasive mass during laboratory testing.

\section{Conclusions.}

Abrasive wear of the tilling machine movable operating parts may not be identified as a simple mechanical process, as the working surface wear rate may be significantly increased by the chemical factor when subject to wear in the real soil.

\section{References} 184-190.

1. Tylczak, J.H. (1992). Abrasive wear. ASM Handbook. Materials Park, OH, ASM International. 18,

2. Kosteczkij, B.I. (1959). Soprotivlenie iznashivaniyu detalej mashin [Resistance to wear of machine parts]. Moskva; Kiev: MAShGIZ [in Russian].

3. Xrushhov, M.M., \& Babichev, M.A. (1970). Abrazivnoe iznashivanie [Abrasive wear]. Moskva: Nauka [in Russian].

4. Xrushhov, M.M., \& Babichev, M.A. (1960). Isledovaniya iznashivaniya metalov [Metal wear studies]. Moskva: AN SSSR [in Russian].

5. Shejman, E.L. (2005). Abrazivny`j iznos. Obzor amerikanskoj pechati [Abrasive wear. Review of the American press]. Trenie i iznos - Friction and wear,Vol. 26, 1, 100-111 [in Russian].

6. Scandell F., \& Scandell, R. (2004). Development of hardfacing material in Fe-Cr-Nb-C system for use under highly abrasive conditions. Mater. Sci. Technol. 2004. Vol. 20. 92-105.

7. Al-Rubaine, K.C. (2000). Equivalent hardness concept and two-body abrasion of iron-base alloys. Wear. Vol. 243, 1-2. 92-100.

8. Hawk J.A., Wilson, R.D., Darks, D.R., \& Catrillar, M.T. (2002). Abrasive wear failures. ASM Handbook. Materials Part, OH, ASM International. 11, 906-921.

9. Tenebaum, M.M. (1966). Iznosostojkost konstrukcionny`x materialov i detalej mashin [Wear resistance of structural materials and machine parts]. Moskva : Mashinostroenie [in Russian].

10. Tenenbaum, M.M. (1976). Soprotivlenie abrazivnomu iznashivaniyu [Abrasion resistance]. Moskva: Mashinostroenie [in Russian]. 
11. Pintaude, G., Sinatora, A., \& Tanaka, D.K. (2003). The effects of abrasive particle size on the sliding friction coefficient of steel using a spiral pin-on- disk apparatus. Wear. 1, 55-59.

12. Gao, Y.X., \& Fan, H. (2002) A micro-mechanism based analysis for size-dependent indentation hardness. J. of Materials Science. 376 4493-4498.

13. Borak, K.V. (2013). Pidvyshchennia znosostiikosti robochykh orhaniv dyskovykh gruntoobrobnykh znariad metodom elektroeroziinoi obrobky [Improve of wear-resistance of working organs of disk tillage tools by the method of electrical erosive processing]. Candidate's thesis. Kharkiv [in Ukrainian].

14. Severnev, M.M., Podlekarev, N.N., Soxadze, V S., \& Kitikov, V.O. (2011). Iznos i koroziya sel`s`koxozyajstvenny`x mashin [Wear and corrosion of agricultural machinery]. Minsk: Belarus. Navuka. [in Russian].

15. Opalka, S.M., Hector, L.G., Schmid, S.R., Reich, R.A., \& Epp, J.M. (1999). Boundary additive effect on abrasive wear during single asperity plowing of 3004 aluminum alloy. J. of Tribology. 121, 384-393. 614-622.

16. De Pellegrin, D.S., \& Stachowiak, G.V. (2004). Sharpness of abrasive particles and surfaces. Wear. 6,

17. Bershtejn, D.B., Kisetova, N.I., Sorokina, E.M., \& Sheko, I.B. (1992). Makrogiometriya i iznashivayushhaya sposobnost pochvenny`x abrazivnix chasticz [Macrogiometry and the abrasive ability of soil abrasive particles]. Trenie i iznos - Friction and wear. 13, 333-339. 
Борак К.В. Вплив рослинних решток на інтенсивність абразивного зношування робочих органів грунтообробних машин

Абразивний знос один з найпоширеніших видів зношування, на його долю припадає до $50 \%$ всіх відмов деталей машин. Дослідження закономірностей процесу абразивного зношування $\epsilon$ безумовно актуальною задачею. В роботі розглянуто вплив хімічного фактору, а саме наявність рослинних решток в абразивній масі, на інтенсивність зношування робочих органів грунтообробних машин. Лабораторні дослідження проводили за методом «крильчатки», а експлуатаційні на універсальному дисковому агрегаті УДА 4,5 в умовах Овруцького району Житомирської області (грунти супіщані). В результаті проведення досліджень 3'ясовано, що при виділені соків (патоки) підвищується інтенсивність абразивного зношування в лабораторних умовах на $13,5 \ldots 21,5 \%$, а в експлуатаційних умовах - на $8 \%$. Результати експлуатаційних досліджень підтверджують лабораторні дослідження, хоча лабораторні дослідження продемонстрували підвищення інтенсивності зношування на 13,5\% більше за експлуатаційні. Дане відхилення пов'язано з більш високою концентрацією рослинних рештків кукурудзи в абразивній масі при проведені лабораторних досліджень. Процес абразивного зношування робочих органів грунтообробних машин не можливо розглядати як простий механічний процес, адже при зношуванні в реальному грунті хімічний фактор може суттєво прискорювати інтенсивність зношування робочих поверхонь.

Ключові слова: робочі органи, грунтообробні машини, абразивний знос, грунт, рослинні рештки 